THE STEPHEN BECHTEL FUND

IMPRINT IN ECOLOGY AND THE ENVIRONMENT

The Stephen Bechtel Fund has established this imprint to promote understanding and conservation of our natural environment. 
The publisher gratefully acknowledges the generous contribution to this book provided by the Stephen Bechtel Fund. 
SHOREBIRD ECOLOGY, CONSERVATION, and MANAGEMENT 
This page intentionally left blank 


\section{SHOREBIRD ECOLOGY, CONSERVATION, and MANAGEMENT}

Mark A. Colwell

\section{甲}

UNIVERSITY OF CALIFORNIA PRESS

Berkeley Los Angeles London 
University of California Press, one of the most distinguished university presses in the United States, enriches lives around the world by advancing scholarship in the humanities, social sciences, and natural sciences. Its activities are supported by the UC Press Foundation and by philanthropic contributions from individuals and institutions. For more information, visit www.ucpress.edu.

For digital version, see the press website.

University of California Press

Berkeley and Los Angeles, California

University of California Press, Ltd.

London, England

(C) 2010 by the Regents of the University of California

Library of Congress Cataloging-in-Publication Data

Colwell, Mark A.

Shorebird ecology, conservation, and management / Mark A. Colwell. p. $\mathrm{cm}$.

Includes bibliographical references and index.

ISBN 978-0-520-26640-7 (cloth : alk. paper)

1. Shore birds. 2. Shore birds-Conservation. I. Title.

QL696.C4C655 2010

$598.3^{\prime} 317-\mathrm{dc} 22$

2010027335

$\begin{array}{lllllllll}18 & 17 & 16 & 15 & 14 & 13 & 12 & 11 & 10\end{array}$

$\begin{array}{llllllllll}10 & 9 & 8 & 7 & 6 & 5 & 4 & 3 & 2 & 1\end{array}$

The paper used in this publication meets the minimum requirements of ANSI/NISO Z39.48-1992 (R 1997)(Permanence of Paper).

Cover photo: Female American Avocet, Baylands Nature Preserve, Palo Alto, California, by Peter LaTourrette, www.birdphotography.com. 
FOR TAMMIE 
This page intentionally left blank 